\title{
総合健診における精度管理
}

一基準值・カットオフ值の考え方一

\section{福武 勝幸}

\section{1.はじめに}

臨床検査值の意味を評価するに当たり, 従来か ら重要な役割を果たしてきた正常值（正常範囲） という言葉は,「正常」という用語に起因する 様々な誤解により, しばしば不適当な方法で利用 されていた。近年, 正常值と正常範囲は, 基準值 と基準範囲という言葉に置き換えられ, 従来の 「正常」という言葉の概念からくる誤解を避ける とともに, カットオフ值 (病態識別值), 治療目 標值, パニック值などとは異なる概念と意味を持 つものとしての理解が浸透しつつある。しかし， その正しい意味での普及は十分とは言えないた め, 今回は基準値の理解とカットオフ值（病態識 別值), 治療目標值, パニック值についての考元 方を述べる。

\section{2. 基準値, 基準範囲の定義}

基準值は, (1)厳密に医学的に健康であると診断 された健常個体（基準個体）が示す定量検査の測 定值と(2)定性検査および上限値と下限值の両方を 求められない定量検査などについて健常個体が示 す測定結果の 2 つの意味に用いる（表 1)。そし て, 基準範囲とは図 1 亿示すように定量検査につ いて, 基準個体が示す基準値のうち 95\%を含む 中央部の範囲を示す用語として用いる。したがっ て,この值は必ずしも普遍的なものではなく, 基 準個体の選択基準, 測定系の条件, 統計処理方法 などの影響を受けるものであり,これらの条件が

Quality Management in Health Care Data-Understanding of Reference Value and Cut Off Value東京医科大学臨床病理学教室
明記されることが重要な意味を持つものである。 基準個体群と疾患保有群が明らかに分離できる検 查についての基準範囲と疾患との関係は図 2 に示

表 1 基準值（範囲）とは

\begin{tabular}{|c|c|}
\hline 基筆個体 & 医学的に位康な個体 \\
\hline 基蕅值 & 卦筷個体の测定值 \\
\hline \multirow{2}{*}{ 基筷籍围 } & $\begin{array}{l}\text { 基策個体120唰以上の測定值のうち. } \\
\text { 中央部分の 95\% が含まれる笵囲 }\end{array}$ \\
\hline & $\begin{array}{l}\text { 一般に基蓝個体の平均值士2SD } \\
\text { (中央部分の 95. 45\%) }\end{array}$ \\
\hline
\end{tabular}

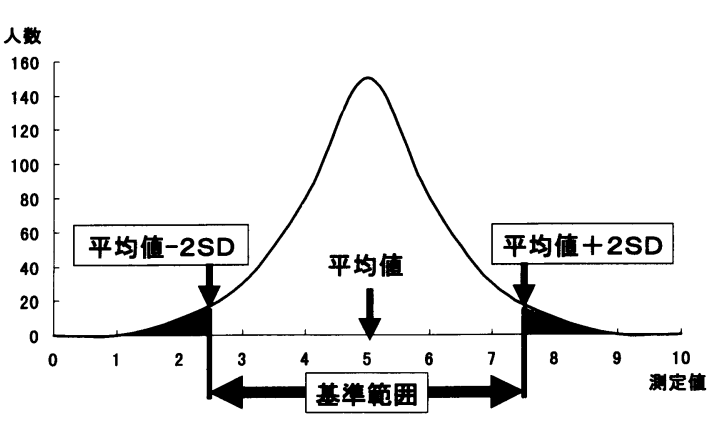

図 1 基準範囲の設定法

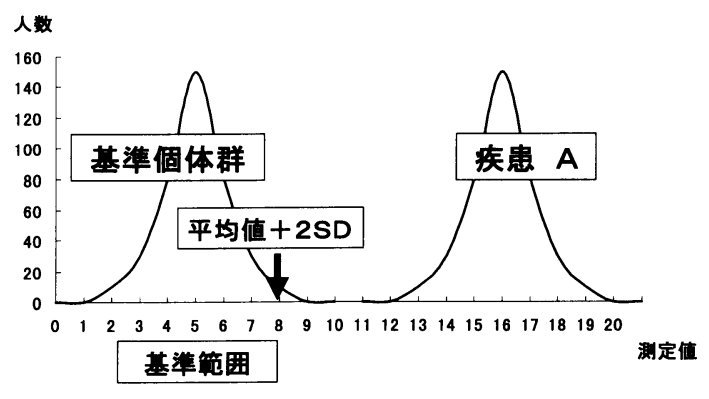

図 2 基準範囲と疾患の関係 
表 2 基準範囲

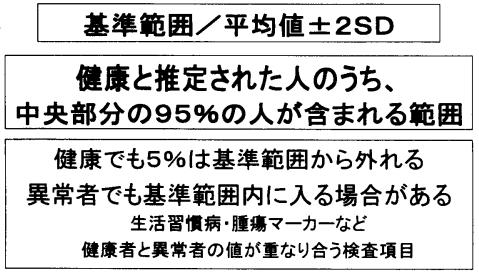

すようになる。

この基準範囲の意味を巡って多くの誤解があ り, 混乱の元になっている。かつて使われた正常 值や正常範囲という語句による誤解が引き継がれ ている。本来の意味は基準範囲の内にあることが 「正常」ないし「病気ではない」ことを保障する ものではないのである。例えば，疾患の初期にお いては検査值の変化はわずかであり，基準範囲の 中にある可能性は高いし，ウイルス感染症の抗体 検査ではウインドウピリオドにおいては陰性を示 すことは周知の事実である。また，健常個体の 5\%は原理的に基準範囲の外にあるのであり偽陽 性となる。すなわち，この範囲から外れているこ とが「異常」ないし「病気である」ことを直ちに 示すものでもないことを認識していなければなら ない（表 2)。

\section{3. カットオフ值 (病態識別値)}

カットオフ値とは前述した基準值や基準範囲と は全く異なる概念の值であり, 疾病の診断を目的 として ROC 曲線等を用いて求めた客観的根拠に 基づいて設定した值である。したがって，基準個 体群と疾患保有群が明らかに分離している場合は 両者の中央にカットオフ值をとることにより偽陰 性・偽陽性を生じることなく診断を確定すること ができる（図 3)。しかし, 現実には基準個体群 と疾患保有群との検査値が重なり合っていること も多い。図 4 に示すように両群が重なり合う中に カットオフ值を設定することになるため, 偽陰性 と偽陽性が生じる。カットオフ值をどこに設定す べきかは検査の目的, 病気の重大性などと検査值 の関係から客観的根拠のもとに決定されるべきで あり, 日本動脈硬化学会が定めた総コレステロー ルの上限值のように, 多くの検查施設の基準範囲

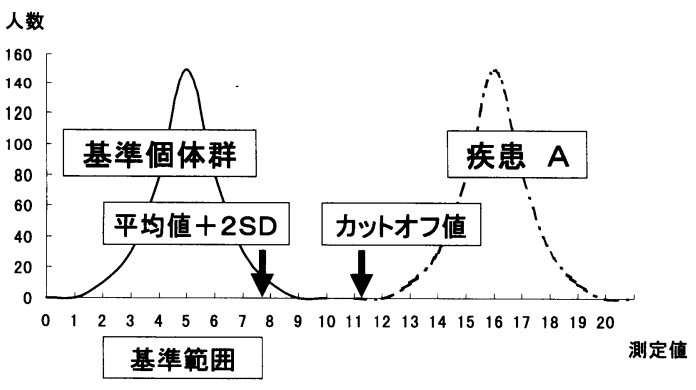

図 3 基準範囲とカットオフ值 (1)

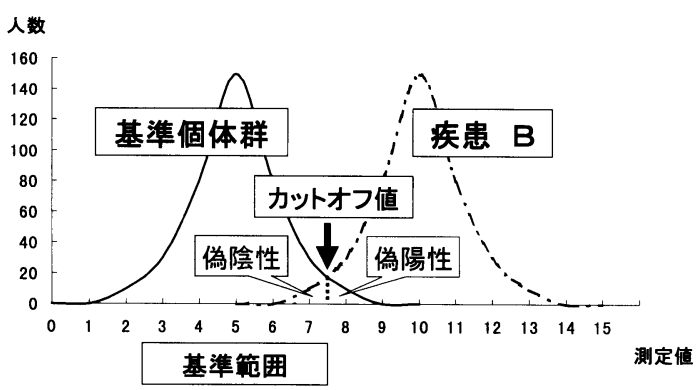

図 4 基準範囲とカットオフ值 ( 2)

の内側に設定されることもある。検査室において は, ELISA の吸光度から反応の陽性を決めるた めの值としてカットオフ值という言葉が用いられ ているが，ここで述べるものはこれとは全く違う ものであり, 病態を判定する臨床的カットオフ值 について述べるので混同しないように願いたい。 すなわち，測定值がその值を越えることが病態の 存在を識別するために重要な意味を持つもので, 直接診断に結びついたり精密検査を指示すること になる。ただし，カットオフ值の定義にはあいま いな部分があり, 同一疾患に対する同一検査にお いても，検査の目的が疾患の見逃しを少なくする ことであるか, 推定疾患の中から可能性の少ない ものを除外することであるのかによってカットオ フ值の設定が異なることになる。すなわち，ある 検査項目で高值を示すことで疾病を診断する場 合, カットオフ值を低く設定すると, 疾病を見逃 す危険は少なくなるが，逆に健常者を疾病あり (偽陽性) と判定する可能性が高くなることにな る（図 5)。しかし，このカットオフ值は普遍的 なものではなく，測定条件による影響を受けるも のである。施設間差のほとんどない標準化の進ん 


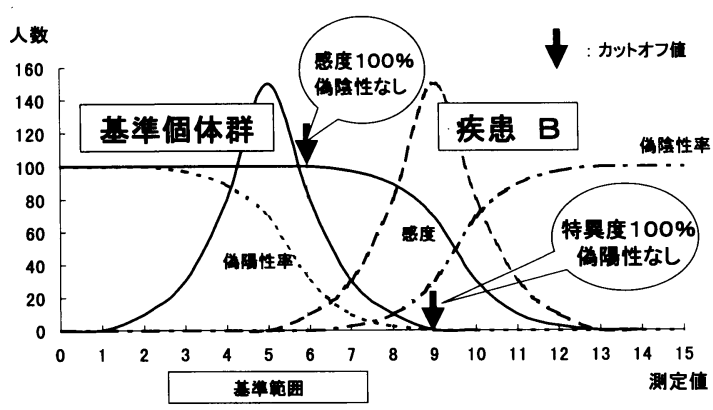

図 5 基準範囲とカットオフ値

だ検査法によるものであれば単一の值となるが, 測定系により異なる值となる場合が多いことにも 注意を払う必要がある。測定法による差，施設間 差を解消することもカットオフ值を有効に用いる ために重要な課題である。

客観的根拠に基づいて直接診断に使われている カットオフ值としては, 糖尿病診断のための血糖 值, 高コレステロール血症における血清コレステ ロール值, 循環障害を招く多血症のへマトクリッ 卜值や痛風発作の可能性を示す尿酸值などがあ る。腫瘍マーカーの検查では精密検査の適応の判 定などのために, 客観的な根拠に基づいたカット オフ值の設定が行われている。しかし，その他の 血液学検査や生化学検査にははっきりした根拠を 持つカットオフ值が設定されていないため, 担当 医の経験により判断されているのが現状である。 これらの検査結果において, 基準範囲を越えたこ とをもって再検査や精密検査の基準とすれば多く の過唾診断による病人作りをする結果になり，多 くの受診者に多大な負担をかけることになる。健 常者と疾患保有群の分離がよい検査法, すなわち 病態識別能力の高い検査法を選択し, 検査の目的 に合った適正なカットオフ值を得るためには様久 なカットオフ值を仮定して感度と偽陽性率を求め てグラフ化した ROC 曲線（図 6）が参考になる。 これからの健診はすべての検查項目について，検 査項目ごと, または複合的な評価によって, 客観 的な根拠に基づいたカットオフ值を設定し, 受診 者に対して適正で具体的な評価を還元することが できるようにしなくてはならない。真に病的な問 題を含む可能性があるレベルをカットオフ值とし

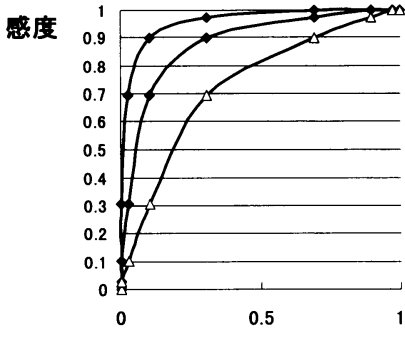

ーー病態別能が高い

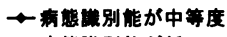

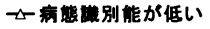

図 $6 \mathrm{ROC}$ 曲線と病態識別能

て設定しなくてはならない。

\section{4. 治療目標値}

治療目標值は治療の開始を推将するものや治療 中の理想的な管理值を示すものである。糖尿病や 高コレステロール血症の診断基準や治療管理基準 が使われている。施設間差のない標準化の進んだ 検査法によるものであれば単一の值となるが，一 般的には測定法別に示さなければならない。

\section{5. パニック值}

パニック值は, 総合健診の中で遭遇することは 少ないと思われるが，重篤な疾患である可能性が 高く, 緊急に対応しなければならない值である。 自覚症状に乏しいものとして比較的頻度が高いの は強度の貧血や血小板減少などであろう。

\section{6. 個人健常範囲と基準範囲}

総合健診を重ねて受診した場合には，個人の 健常範囲をある程度把握できている人も少なくな い。そして, 個人の健常範囲が基準範囲の中の狭 い限定された領域に存在している個人において は，その範囲を参照することが将来の異常事態の 発生を早期に鋭敏に検出するために有用な評価基 準になると思われる。しかし, 適切な個人の健常 範囲を決めるためには，解決しなければならない 問題がある。すなわち, 標準的な個人の変動範囲 についての知見が検查項目ごとに必要である。個 人内の変動に影響する因子についても項目ごとに 知見が必要である。当然であるが，すでに疾患に 罹患している個人においてはその健常範囲を決め ることは困難であるし，基準範囲を大きく超えて 
いる個人においても個人の健常範囲の設定が困難 である。個人の健常範囲の幅と基準範囲の幅は検 査項目により大きく異なっており，利用の方法を 誤ると逆に診断を逃すことも考えられる。また， 一般に生命維持に密接にかかわる物質ほど個人差 が少なく, 基準範囲と個人の健常範囲が近くなる ために, それらの項目では個人の健常範囲の臨床 的な意義は少なくなると考えられる。

\section{7. 基準範囲，カットオフ值（病態識別値）, 治療目標値の利用}

検査値を利用する場合は検査の目的と役割に応 じた用い方をしなければならない。検査の目的と しては, (1)疾患の発見と診断, (2)推定疾患を把握 した後の除外診断, (3)病態把握, (4)重症度・活動 性の把握, (5)治療効果の判定, 66経過観察等があ る。それぞれの目的に応じた検查值の利用が必要 であり，基準となる值を測定法の感度や特異度を 基に設定しなければならない。

これらのうち総合健診にとって重要なのは, 主 に(1)と(2)である。(1)の目的において, 感度を高め るには基準範囲を外れたものをすべて疑うことで あり,この場合のカットオフ值は基準範囲と等し くなる。しかし，これでは一般に特異度が下がる ため病気のない人を多く精密検査しなくてはなら なくなる。そこで，それぞれの検査の特異度と目 的疾患の有病率, 死亡率, 治療法の有無や早期診 断の有益性を加味して算出した，総合健診として 最も合理的なカットオフ值を設定することが重要 であり, 今後の総合健診の課題である。一方, 生 活習慣病の代表である高コレステロール血症は， 近年の日本では日常的に見られるため, 多くの施 設の基準範囲の中に診断のためのカットオフ值と 治療目標值が含まれている。これは基準範囲と カットオフ值や治療目標值が全く異なる概念の基 に設定されていることを示している。また，同時 に基準範囲の本来の定義である健常者の測定值で なければならないこととの矛盾も示しており，生
活習慣病に関連する検査項目のように検査值自身 により診断される疾患においては基準範囲として 本来の定義を満たす設定は困難であり, 無症候状 態の疾患領域を含む地域集団の現状を示す值とし て基準範囲を理解しなければならない。

\section{8. 精度管理と基準範囲}

これまでの精度管理の基本的な目的は施設ごと の正確度と精密度の確保のための内部精度管理で あった。しかし，これだけでは基準範囲，カット オフ值, 治療目標值を活用して, 施設間差の少な い医療を実現することができない。外部精度管理 として多施設参加による施設間精度管理が本格的 に行われるようになり，施設間差の縮小を目標と して推進されている。臨床検査の標準化が実現し たとき，基準範囲が統合され多施設の成績を全国 共通の指標として検討できるようになる。また, 様々な疾患に対するカットオフ值や治療目標值も 全国共通の指標として使える本格的な参照值とし て設定することが可能になり，施設間差に関する 精度も高めることができる。

\section{9. おわりに}

検査項目によっては, クレアチニンのように異 常高值により腎障害を直接診断できるものもある が，赤沈や CRP のように疾患特異性が低く，間 接的に疾患の存在を疑わせるものもある。血液へ モグロビンでは軽度の低下は様々な疾患の存在を 疑わせ，顕著な低下では貧血症自身の診断も加わ るというように，異常の度合いによって両者の性 質を併せ持つものもある。検査法の性質を把握 し, 実際の診断的価值を確認し, 客観的根拠に基 づいて総合健診における精密検査の判断や診断の ためのカットオフ值を設定することが重要であ る。また，検査法の標準化を促進し，基準範囲や カットオフ值などを全国共通の指標として用いる ことができるようにしなければならない。 